\title{
Treatment of Vesico-ureteric Reflux in Children
}

\author{
JOHN E. S. SCOTT and J. M. STANSFELD \\ From the Departments of Surgery and Child Health, University of Newcastle upon Tyne, \\ and United Newcastle upon Tyne Hospitals
}

Approximately $35 \%$ of children with urinary infection have vesico-ureteric reflux (McGovern, Marshall, and Paquin, 1960; Ericsson, 1960). It is not known whether infection causes the reflux by damaging the uretero-vesical valvular mechanism, or whether a congenital abnormality permits reflux which predisposes to infection. Yet whatever the aetiology, it seems logical to assume that when infection occurs in the presence of reflux there will be renal involvement, for it has been shown that there is a close correlation between ureteric reflux and radiological evidence of kidney scarring (Hodson and Edwards, 1960). Despite this, it is not clear whether, besides treating the infection by giving prolonged carefully controlled courses of antibiotics, the child will gain additional benefit if a surgical operation is undertaken to eliminate the reflux.

The purpose of this paper is to report the results of a controlled trial in which a group of children with surgically treated reflux was compared with an unoperated group. The trial was a prospective one and the children were allotted at random to either the operated or control groups according to whether their birthdays fell on even or odd days. In view of the considerable divergence of opinion about the value of the surgical treatment of reflux (Spence $e t$ al., 1961) and the uncomplicated nature of this type of surgery, it was felt that it was ethically justifiable to conduct a trial in this manner. 58 children were studied, 33 having operations for their reflux and 25 acting as controls. Cases in which reflux was associated either with mechanical obstruction in the urethra, such as posterior urethral valves, or with neurogenic bladder, were excluded from the trial, as it was felt that in these the treatment of the reflux could not be considered in isolation but only as a part of the management of the associated condition.

\section{Diagnosis}

All the children placed in the trial had had one or more attacks of urinary infection proven by the finding in

Received October 26, 1967. clean specimens of their urine of more than 10 pus cells per c.mm. (Stansfeld, 1962) and more than 100,000 organisms per ml. (Kass, 1957).

Ureteric reflux was diagnosed by cystographic examination performed by one of the authors (J.E.S.S.). The bladder was catheterized and emptied. $20 \%$ Hypaque solution was then injected through the catheter until the child expressed a desire to micturate, at which time an $x$-ray including the whole abdomen was taken with the child supine. Female children were then sat on a commode and a true lateral exposure of the bladder and urethra was made during micturition. In male children the micturating radiograph was taken with the pelvis in an oblique position and the child either lying supine or standing erect. As soon as the child had finished micturating a third exposure was made in a manner similar to the first, that is of the whole abdomen with the child supine. The examination was performed without anaesthesia in all children over the age of 4. Younger children were anaesthetized and their bladders expressed manually in order to obtain the micturating films.

As well as the cystogram all children had an intravenous pyelogram and cystoscopy.

\section{Conduct of Trial}

In the early stages of the trial some of the children were thought to have non-mechanical bladder neck obstruction as well as reflux, and these were subjected to a plastic operation on the bladder neck, irrespective of whether they were in the operation or control groups. Subsequently, we came to doubt whether 'functional' obstruction of the bladder neck was a true entity, and in the last half of the trial this diagnosis was not made (Scott, 1968).

All cases were observed for 3 years. They were seen monthly at first, but later, according to progress, the intervals might be extended to 2 or 3 months. At each attendance symptoms were recorded, the child examined, blood pressure measured, and a urine pus cell count done. Whenever there were symptoms or pyuria was demonstrated, urine bacterial counts were also made. Operated cases had a cystogram 6 months after operation, and all cases, whether in operated or control groups, were readmitted to hospital at the end of 3 years for a repeat of all the investigations that were done at the beginning of the trial.

Two of the control group were not infected at the 
time that they were admitted to the series, and as they had no relapse they were not given any antibiotics. All others had intensive medical treatment, antibiotics being selected according to the sensitivities of the organisms grown from their urines. Treatment was stopped only when several months had passed without evidence of activity. In the majority it was given for at least 6 months, and in those who developed recurrences of infection it was continued for a year or longer.

\section{TABLE I}

\section{Anti-reflux Operations and Outcome}

\begin{tabular}{|c|c|c|c|c|c|}
\hline \multirow{2}{*}{\multicolumn{2}{|c|}{$\begin{array}{c}\text { Type of } \\
\text { Operation }\end{array}$}} & \multicolumn{2}{|c|}{ Operations } & \multicolumn{2}{|c|}{ Failures } \\
\hline & & Cases & Ureters & Cases & Ureters \\
\hline $\begin{array}{l}\text { Bischoff .. } \\
\text { Advancement } \\
\text { Reimplant } \quad \text {. }\end{array}$ & $\begin{array}{l}\cdots \\
\cdots \\
\cdots\end{array}$ & $\begin{array}{r}6 \\
5 \\
20\end{array}$ & $\begin{array}{r}9 \\
6 \\
31\end{array}$ & $\begin{array}{l}4 \\
2 \\
0\end{array}$ & $\begin{array}{l}5 \\
3 \\
0\end{array}$ \\
\hline Total & $\ldots$ & 31 & 46 & 6 & 8 \\
\hline
\end{tabular}

TABLE II

Second Operations for Reflux and Outcome

\begin{tabular}{|c|c|c|c|c|}
\hline \multirow{2}{*}{$\begin{array}{l}\text { Type of } \\
\text { Operation }\end{array}$} & \multicolumn{2}{|c|}{ Operations } & \multicolumn{2}{|c|}{ Failures } \\
\hline & Cases & Ureters & Cases & Ureters \\
\hline $\begin{array}{l}\text { Bischoff } \rightarrow \text { reimplant } \\
\text { Advancement } \rightarrow \text { reimplant } \\
\text { Total } \quad . . \quad \ldots \quad \text {. }\end{array}$ & $\begin{array}{l}2 \\
1 \\
3\end{array}$ & $\begin{array}{l}2 \\
1 \\
3\end{array}$ & $\begin{array}{l}0 \\
1 \\
1\end{array}$ & $\begin{array}{l}0 \\
1 \\
1\end{array}$ \\
\hline
\end{tabular}

TABLE III

Bladder Neck Operations

\begin{tabular}{lcc|c|c|c}
\hline & & $\begin{array}{c}\text { Operation } \\
\text { Group }\end{array}$ & $\begin{array}{c}\text { Control } \\
\text { Group }\end{array}$ & Total \\
\hline $\begin{array}{l}\text { Y-V plasty } \\
\text { Muscle division }\end{array}$ & $\ldots$ & $\ldots$ & 8 & 6 & 14 \\
\hline Total $\ldots$ & $\ldots$ & $\ldots$ & 11 & 3 & 6 \\
\hline
\end{tabular}

\section{Anti-reflux Operations}

The efficiency of these operations has been examined in a previous report (Scott, 1966). Although it is now possible to guarantee in a suitable case that reflux can be eliminated by means of the ureteric reimplantation operation, some of the early cases in this series were treated by other operations with less success (Table I). There were 6 children with 8 ureters in which the antireflux operation was a failure. 3 of these children had second operations (Table II), the original procedure being replaced by ureteric reimplantation. In 2 this was successful but in the third, though the reflux had apparently been eliminated 6 months after operation, it was again seen in a cystogram 3 years later. Besides the operation failures there were another 4 children in whom unilateral reflux was successfully treated but reflux appeared in the opposite ureter at a later date. Altogether then there were 8 children in the operation group who had persistent reflux in 10 of their ureters, whether on operated or unoperated sides at either 6 months, 3 years, or both. It was decided that for the purposes of the trial these cases should be withdrawn from the operation group.

Open revision of the bladder neck was carried out in 20 children. In 14 a Y-V plasty was done and in 6 the operation was limited to division of the muscle fibres across the anterior margin of the bladder neck. These cases were evenly distributed between the two groups (Table III).

\section{Results}

Two of the operated cases and one control could not be traced at the end of the 3-year period and were excluded from the trial. As previously mentioned, 8 cases in the operation group were also excluded because their reflux had persisted. With these adjustments, there remained 23 sucessfully operated cases for comparison with 24 controls. The two groups were well matched (Tables IV and V). There were no significant differences in sex, age at onset, length of history, and previous treatments, nor in radiological and cystoscopic findings.

Reflux in control cases. During the 3-year period, there was a change in the state of reflux in 11 cases in the control group. In 6 the reflux, which had been unilateral in all but 1 , disappeared completely. In 2 further cases with bilateral reflux, there was spontaneous disappearance on one side only. The remaining 3 children had unilateral reflux at the beginning of the 3-year period, and bilateral reflux at the end. Thus in the control cases reflux disappeared spontaneously in $9(27 \%)$ of 33 refluxing ureters, and appeared in $3(21 \%)$ of 14 ureters originally without demonstrable reflux. The only outstanding feature about the 6 children in whom reflux disappeared entirely was that it was unilateral in 5 of them. They did not differ significantly in any other respect from the remainder of this group.

Urinary infection. Relapse of infection occurred in $\mathbf{1 0}$ children in the operated group and in $\mathbf{1 6}$ in the control group (Table VI). The difference between the groups was not large; however, not only did more of the controls become reinfected but they tended to do so more frequently. During the 3-year period only 2 of the operated group had more than one relapse compared with 8 of the 
controls. There were altogether 14 relapses amongst the children in the operated group and 32 in the control group. The difference seems unlikely to be a chance variation $\left(\chi^{2}=6 \cdot 4\right.$; $\mathrm{n}=1 ; 0.02>\mathrm{p}>0.01)$. There was, therefore, a significantly higher incidence of relapse of infection amongst the children in the control group.

Kidney growth. The intravenous pyelogram films taken at the beginning and end of the 3-year period were carefully studied and the length of the kidneys measured. By using the whole series of films from each pyelographic investigation it was possible to delineate the upper and lower poles of the kidneys with reasonable accuracy. From these measurements, the change in the length of the kidneys was estimated and then corrected to provide a growth rate in $\mathrm{mm}$. over a period of exactly 3 years. According to Hodson et al. (1962), increase in kidney length is a satisfactory guide to over-all kidney growth which normally proceeds at a constant rate between the ages of 4 and 15 years. Both kidneys in the same individual grow at approximately the same speed and do not usually differ in length by more than $5 \mathrm{~mm}$. Kidneys that are infected tend to grow at a slower rate than normal. If bilaterally involved, the growth on the two sides may be equally depressed, but if only one kidney is affected it may well fail to grow while the opposite healthy kidney enlarges at a rate in excess of normal. Thus, one of the aims of treatment in a child with urinary infection and reflux is to achieve normal and equal kidney growth.

In Table VII details are given of the 3-year changes of kidney length in operation and control cases. Fig. 1 and 2 also show these graphically.

The following features seem evident. (1) Shrinking occurred in 2 kidneys in the operation group and 7 kidneys in the control group. (2) In 13 of the operated cases and 18 of the controls there was
TABLE IV

Comparison of Operation and Control Cases at Beginning of Trial

\begin{tabular}{|c|c|c|c|c|c|}
\hline & & & & $\begin{array}{l}\text { Operation } \\
\text { Group } \\
(23 \text { cases })\end{array}$ & $\begin{array}{l}\text { Control } \\
\text { Group } \\
\text { (24 cases) }\end{array}$ \\
\hline $\begin{array}{l}\text { Sex } \\
\stackrel{\text { Male }}{\text { Female }}\end{array}$ & $\begin{array}{l}\cdots \\
\cdots\end{array}$ & $\begin{array}{l}\cdots \\
\cdots\end{array}$ & $\begin{array}{l}\cdots \\
\cdots\end{array}$ & $\begin{array}{r}4 \\
19\end{array}$ & $\begin{array}{r}3 \\
21\end{array}$ \\
\hline $\begin{array}{c}\text { Age at onset of syn } \\
<1 \text { year.. } \\
1-5 \text { years } \\
>5 \text { years }\end{array}$ & $\begin{array}{l}m p t \\
\cdots \\
\cdots \\
\cdots\end{array}$ & $\begin{array}{l} \\
\ldots \\
\ldots\end{array}$ & \begin{tabular}{l|}
$\cdots$ \\
$\cdots$ \\
$\cdots$
\end{tabular} & $\begin{array}{r}6 \\
12 \\
5\end{array}$ & $\begin{array}{r}4 \\
13 \\
7\end{array}$ \\
\hline $\begin{array}{l}\text { Length of history } \\
<1 \text { month } \\
1 \text { month-1 year } \\
>1 \text { year. }\end{array}$ & $\begin{array}{c}\ldots \\
\ldots\end{array}$ & $\begin{array}{l}\cdots \\
\cdots \\
\cdots\end{array}$ & $\begin{array}{l}\cdots \\
\cdots \\
\cdots\end{array}$ & $\begin{array}{r}0 \\
5 \\
18\end{array}$ & $\begin{array}{r}0 \\
6 \\
18\end{array}$ \\
\hline $\begin{array}{l}\text { Previous antibiotic } \\
\text { None } \quad . \\
\text { One course } \\
>\text { one course }\end{array}$ & $\begin{array}{l}\text { tr } \\
\cdots \\
\cdots \\
\cdots\end{array}$ & $\begin{array}{c}\text { nent } \\
\ldots \\
\ldots \\
\cdots\end{array}$ & $\begin{array}{l}\cdots \\
\cdots \\
\cdots\end{array}$ & $\begin{array}{r}3 \\
11 \\
9\end{array}$ & $\begin{array}{l}8 \\
8 \\
8\end{array}$ \\
\hline
\end{tabular}

TABLE V

Radiological Findings in Operation and Control Cases at Beginning of Trial

\begin{tabular}{|c|c|c|c|c|}
\hline & \multicolumn{2}{|c|}{$\begin{array}{l}\text { Pyelonephritic } \\
\text { Scarring }\end{array}$} & \multicolumn{2}{|c|}{ Reflux } \\
\hline & Present & Absent & Unilateral & Bilateral \\
\hline $\begin{array}{l}\text { Operation group } \\
\text { ( } 23 \text { cases }) \\
\text { Control group } \\
(24 \text { cases })\end{array}$ & $\begin{array}{l}15 \\
17\end{array}$ & $\begin{array}{l}8 \\
7\end{array}$ & $\begin{array}{l}11 \\
13\end{array}$ & $\begin{array}{l}12 \\
11\end{array}$ \\
\hline
\end{tabular}

a disparity in the rate of growth of the 2 kidneys greater than $5 \mathrm{~mm}$. in 3 years. (3) In general, when there was persistent unilateral reflux, the kidney on the affected side did not grow as well as its contralateral fellow. (4) The mean growth rate in

TABLE VI

Urinary Infections During 3-year Period

\begin{tabular}{|c|c|c|c|c|c|c|c|}
\hline & & & & & & $\begin{array}{c}\text { Operation Group } \\
\text { (23 cases })\end{array}$ & $\begin{array}{l}\text { Control Group } \\
\text { (24 cases) }\end{array}$ \\
\hline Reinfections during 3 years & $\cdots$ & $\cdots$ & . & \{ & $\begin{array}{l}0 \\
1 \\
\text { Multiple }\end{array}$ & $\begin{array}{r}13 \\
8 \\
2\end{array}$ & $\begin{array}{l}8 \\
8 \\
8\end{array}$ \\
\hline Urine at time of follow up & $\cdots$ & . & $\cdots$ & . & $\begin{array}{l}\text { Sterile } \\
\text { Infected }\end{array}$ & $\begin{array}{r}21 \\
2\end{array}$ & $\begin{array}{r}20 \\
4\end{array}$ \\
\hline \multicolumn{3}{|c|}{ Antibiotic treatment at time of follow up } & . & $\ldots \quad\{$ & $\begin{array}{l}\text { Discontinued } \\
\text { Still on treatment }\end{array}$ & $\begin{array}{r}19 \\
4\end{array}$ & $\begin{array}{r}15 \\
9\end{array}$ \\
\hline
\end{tabular}




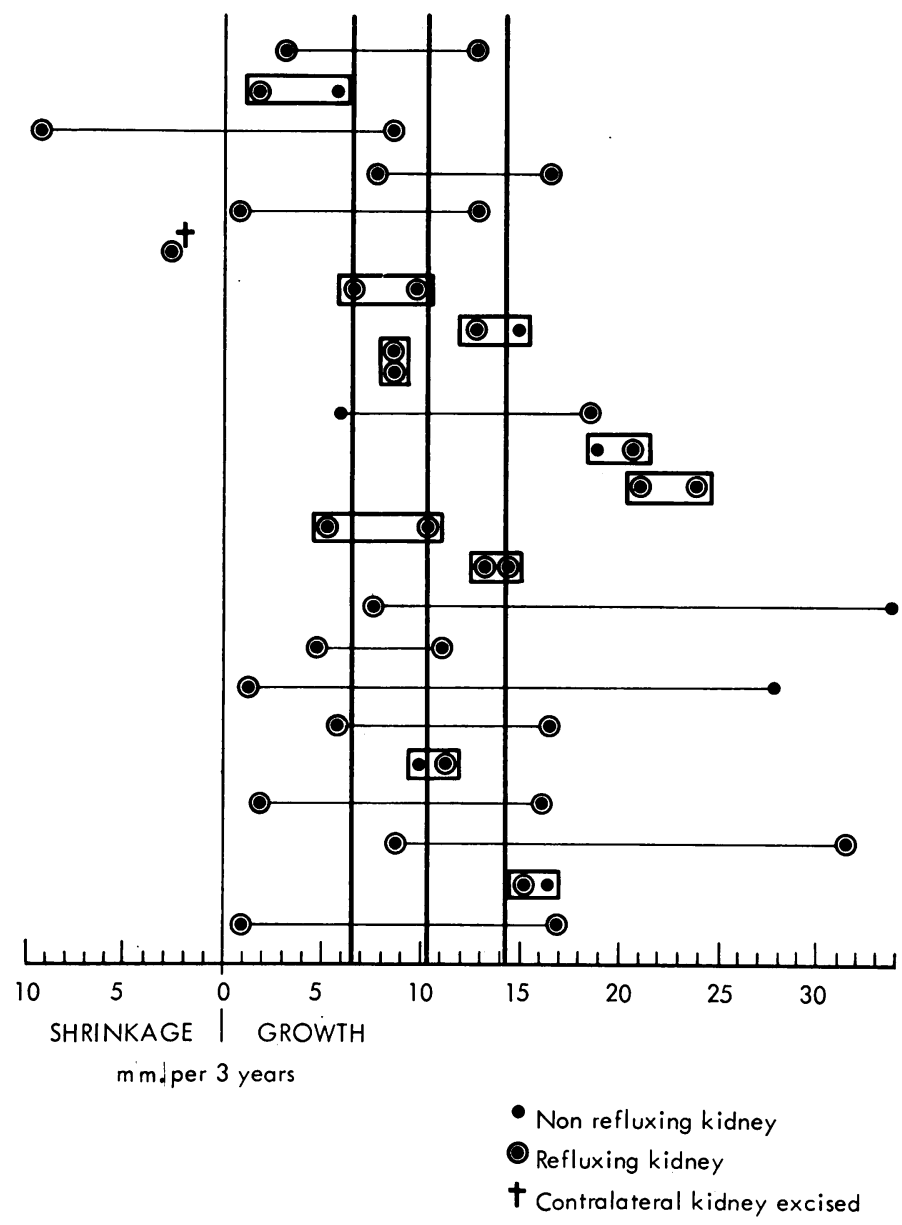

FIG. 1 and 2 (above and opposite).-Kidney growth rate in $\mathrm{mm}$. per three years in each of the cases in the series. The heavy vertical lines indicate the mean normal growth rate and the mean $\pm 2 \frac{1}{2} S D$. Each horizontal line represents one case. The symbols in boxes represent pairs of kidneys with a growth rate equal to within $5 \mathrm{~mm}$.

the operation group was greater than in the control group. The difference was even more marked when kidneys whose reflux had been abolished by operation were compared with those with persistent reflux in the control group. It is unlikely that the differences between the means for kidney growth in the main or subgroups are due to chance variation (Table VII). Although these figures appear to be statistically significant, they are based on measurements of kidney length as seen on radiographs, and despite every effort to ensure accuracy, it is possible that some of them are erroneous since the renal outline was occasionally difficult to see.

\section{Discussion}

This trial has not been ideal. The number of cases included is small and it was known which cases had had operations and which were controls so that there may have been an unconscious bias in assessing the results. However, while the trial was in progress we were disappointed that re-infections occurred so frequently in both groups, and up to the final analysis of the results we were inclined to think that operative treatment of the reflux had been of little value. Nevertheless, despite the limitations of the trial the findings do suggest that the surgical elimination of reflux in a child with 
CONTROL CASES

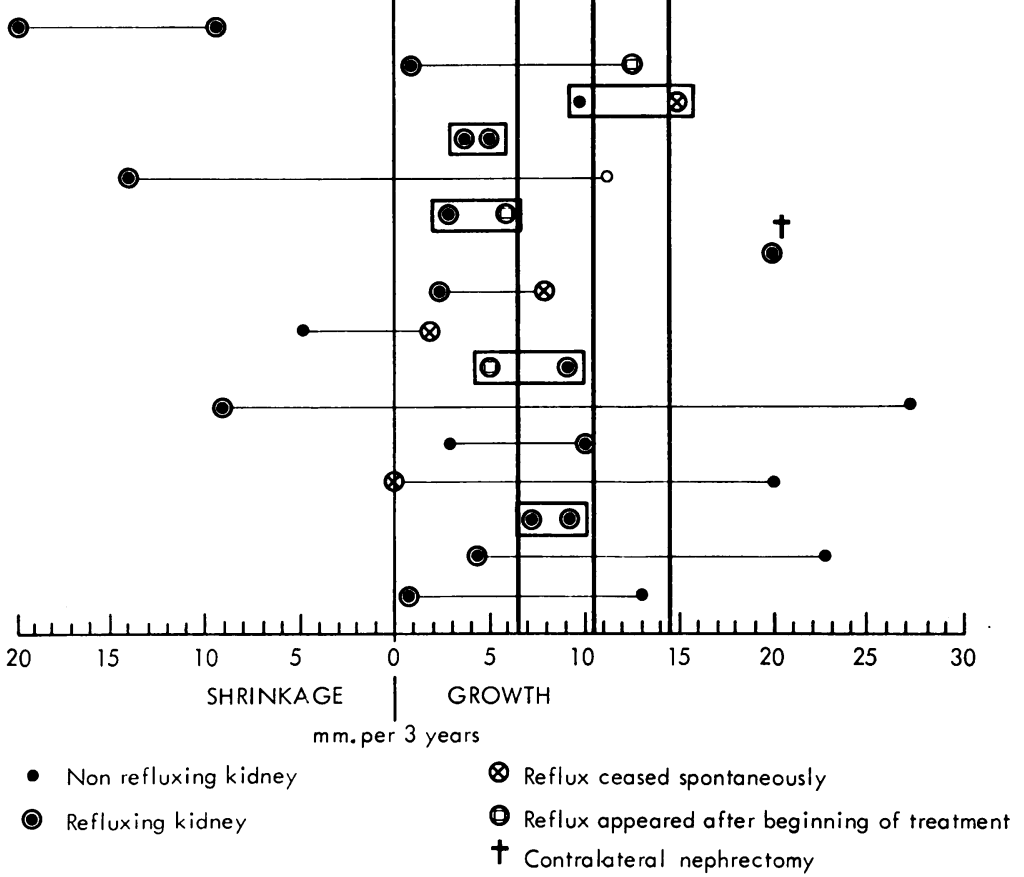

TABLE VII

Growth of Kidneys During 3-year Period

\begin{tabular}{|c|c|c|c|c|c|c|c|}
\hline & Number & $\begin{array}{c}\text { Range of Length } \\
\text { Change in } 3 \text { Years } \\
(\mathrm{mm} .)\end{array}$ & $\begin{array}{c}\text { Mean } 3 \text { Year } \\
\text { Growth } \\
(\mathrm{mm} .)\end{array}$ & $S(n-1)$ & $S E_{\bar{X}}^{-}$ & $\mathbf{t}$ & $\mathbf{p}$ \\
\hline $\begin{array}{l}\text { All kidneys } \\
\text { Operation group } \\
(23 \text { cases }) . . \\
\text { Control group } \\
(24 \text { cases }) . .\end{array}$ & $\begin{array}{l}45 \\
47\end{array}$ & $\begin{array}{l}-9 \cdot 4 \text { to }+31 \cdot 5 \\
-19 \cdot 8 \text { to }+27 \cdot 0\end{array}$ & $\begin{array}{r}11 \cdot 10 \\
5 \cdot 88\end{array}$ & $\begin{array}{l}8 \cdot 26 \\
8 \cdot 86\end{array}$ & $\begin{array}{l}1 \cdot 23 \\
1 \cdot 29\end{array}$ & $2 \cdot 93$ & $<0.01$ \\
\hline $\begin{array}{l}\text { Kidneys with refluxing } \\
\text { ureters } \\
\text { Operation group } \\
\text { (reflux stopped) } \\
\text { Control group } \\
\text { (reflux persistent) }\end{array}$ & $\begin{array}{l}37 \\
25\end{array}$ & $\begin{array}{l}-9.4 \text { to }+31.5 \\
-19 \cdot 8 \text { to }+20.0\end{array}$ & $\begin{array}{r}10 \cdot 09 \\
2 \cdot 73\end{array}$ & $\begin{array}{l}7 \cdot 97 \\
8 \cdot 85\end{array}$ & $\begin{array}{l}1 \cdot 31 \\
1 \cdot 77\end{array}$ & $3 \cdot 34$ & $<0.01$ \\
\hline
\end{tabular}


urinary tract infection will reduce to some extent the likelihood of further infection and help to protect the kidney from scarring. Even so, we do not wish to suggest that surgery should be advised for every child with ureteric reflux. In those with unilateral reflux with no dilatation of the upper urinary tract, minimal pyelonephritic scarring, and a short history of urinary infection, it may be justifiable to recommend conservative non-operative treatment. Such a decision places on the clinician the responsibility for carefully observing the child to ensure that the infection is kept under control. It is also advisable to repeat the cystogram after one year. If the infection relapses and the reflux does not disappear spontaneously, there are then strong indications for surgery.

\section{Summary}

Fifty-eight children with urinary infection and vesico-ureteric reflux were placed in a controlled trial designed to determine the effectiveness of surgery in this condition.

An anti-reflux operation was performed on children selected by a random method. The cases were then followed for 3 years and the incidence of urinary infection and kidney growth rates were assessed in the operated and unoperated cases.

It was found that the incidence of urinary infection was higher and the mean kidney growth rate lower in the unoperated cases.

\section{REFERENCES}

Ericsson, N. O. (1960). Urinary tract infections. II. Urologic viewpoints on the treatment of urinary tract infections in children. Acta paediat. (Uppsala), 49, 196.

Hodson, C. J., Drewe, J. A., Karn, M. N., and King, A. (1962). Renal size in normal children. A radiographic study during life. Arch. Dis. Childh., 37, 616.

- , and Edwards, D. (1960). Chronic pyelonephritis and vesico-ureteric reflux. Clin. Radiol., 11, 219.

Kass, E. H. (1957). Bacteriuria and the diagnosis of infections of the urinary tract. Arch. intern. Med., 100, 709.

McGovern, J. H., Marshall, V. F., and Paquin, A. J., Jr. (1960). Vesicoureteral regurgitation in children. $\mathcal{F}$. Urol. (Baltimore), $83,122$.

Scott, J. E. S. (1966). Results of operations for ureteric reflux. Arch. Dis. Childh., 41, 165.

- (1968). Paediatric Urology, Chapter 16. Butterworth, London. In the press.

Spence, H. M., Stewart, C. M., Marshall, V. F., Leadbetter, W. F., and Hutch, J. A. (1961). Panel discussion on ureteral reflux in children. $\mathcal{F}$. Urol. (Baltimore), 85, 119.

Stansfeld, J. M. (1962). The measurement and meaning of pyuria. Arch. Dis. Childh., 37, 257. 